\title{
ENERGY-CONSERVING SYNTHESIS OF NANODISPERSED AMORPHOUS SODIUM SILICATE FOR WATER-GLASS PRODUCTION
}

\author{
A. I. Vezentsev, I. D. Tarasova, E. L. Proskurina, and A. P. Pol'shin
}

An energy-conserving, ecologically clean technology for producing water glass has been developed. This technology is based on the use of readily available raw materials. A glassmaking furnace is not used.

\begin{abstract}
Water glass is a colloidal solution of nanodispersed amorphous sodium, potassium, lithium, or ammonium silicate. The main quality indicator for water glass is the silicate modulus - the molar ratio of silicon dioxide to alkali-metal or ammonium oxide. Water glass is used as a binding agent in casting, gluing and sealing material, binder and refractory concretes and heat resistant coatings, anti-corrosion and antiseptic agents, and in the production of heat-insulation materials, silicate paints, washing media, electrodes, cotton fabrics, and a number of other materials.
\end{abstract}

Water glass for these purposes is conventionally produced by dissolving a silicate block which is formed when melt obtained by melting quartz sand together with carbonate of soda in a glassmaking furnace at temperatures $1400-$ $1500^{\circ} \mathrm{C}$ is cooled [1]. This process is very energy-intensive and requires substantial amounts of heat. According to the data from the Kherson Glass Works, $450 \mathrm{~kg}$ fuel equivalent is consumed to obtain $1 \mathrm{t}$ of water glass. A drawback of the conventional commercial method is a limit on the granulometric and chemical compositions of quartz sand. Quartz sand with $0.1-0.8 \mathrm{~mm}$ grains is used in glassmaking technology. Grains larger than $0.8 \mathrm{~mm}$ slowly dissolve in a melt of silicates and may not dissolve completely, forming an undercooked pulp. Grains which are smaller than $0.1 \mathrm{~mm}$ hamper glass fining. In the production of silicate block the mass content of silicon dioxide in quartz sand should not be less than $98.5 \%$. In addition, the drawbacks of the conventional method are the multistage structure of the production process and emission of sulfur, carbon, and nitrogen oxides into the atmosphere, resulting in precipitation in the form of acid rain.
Another method of obtaining water glass presupposes the interaction of activated quartz sand and an alkali solution in an autoclave at temperature $200-250^{\circ} \mathrm{C}$ and pressure $16-$ $25 \mathrm{~atm}[2]$. A drawback of this method is the high working pressure and the need to use special autoclaves with a complex construction.

We have developed an energy-conserving, ecologically clean technology for producing water glass. This technology is based on the use of readily available raw materials. No expensive and energy-intensive equipment, such as a glassmaking furnace, is used.

Quartz sands, silica-containing wastes from metallurgical machine-building enterprises (specifically, the Oskol'skii Metallurgical Machine-Building Works (OMMBW)), molding materials wastes from the Verkhne-Ufaleiskii Metallurgical Machine-Building Works, tripoli, diatomite, and dusty wastes from grinding diatomaceous brick served as the raw materials. Flaked sodium hydroxide (GOST 4328-81) and $\mathrm{RKh}$ grade sodium hydroxide in a technical solution (GOST 2263-79) were used as alkali components.

The compositions of the raw materials are presented in Tables 1 and 2. Chemical analysis shows that the materials used are consist mainly of silicon dioxide, whose mass content varies from 81.54 to $96.01 \%$. Titanium dioxide $(0.26 \%)$ has been found in diatomite from the Inzenskoe deposit.

$\mathrm{x}$-ray phase analysis (DRON-3.0) established that the main crystalline phase of silica-containing materials is the low-temperature modification of trigonal quartz $(0.427$, $0.335,0.246,0.228,0.213,0.198,0.184$, and $0.154 \mathrm{~nm}$ ). Its content in quartz sands and molding materials wastes is $87-96 \%$. 
TABLE 1.

\begin{tabular}{|c|c|c|c|c|c|c|c|c|}
\hline \multirow{2}{*}{ Initial material component } & \multicolumn{8}{|c|}{ Mass content, \% } \\
\hline & $\mathrm{SiO}_{2}$ & $\mathrm{Al}_{2} \mathrm{O}_{3}$ & $\mathrm{Fe}_{2} \mathrm{O}_{3}$ & $\mathrm{FeO}$ & $\mathrm{MgO}$ & $\mathrm{K}_{2} \mathrm{O}$ & $\mathrm{Na}_{2} \mathrm{O}$ & $\mathrm{CaO}$ \\
\hline \multicolumn{9}{|l|}{ Quartz sand from the deposit: } \\
\hline Kichinginskoe & 96.01 & 1.30 & 0.10 & - & 0.76 & - & 0.40 & 0.90 \\
\hline Churovskoe & 87.82 & 4.02 & 2.07 & 0.3 & 0.67 & 0.75 & 1.10 & 1.30 \\
\hline Silica wastes from OMMBW: & & & - & & & & & \\
\hline from terminal hopper & 88.08 & 0.51 & 1.60 & - & 0.61 & - & - & 1.40 \\
\hline from cyclone dust separator & 93.03 & 0.89 & 1.20 & - & 1.00 & - & - & 1.12 \\
\hline Molding wastes & 93.71 & 2.42 & 0.17 & 0.14 & 0.21 & 0.19 & 1.68 & 0.36 \\
\hline \multicolumn{9}{|l|}{ Tripoli from deposits: } \\
\hline Kuteinikskoe & 81.54 & 9.05 & 1.48 & - & 0.59 & 0.90 & 0.30 & 1.61 \\
\hline Fokinskoe & $\begin{array}{c}85.00-9 \\
0.00\end{array}$ & $\begin{array}{c}3.00-10 \\
.00\end{array}$ & 0.90 & - & $\begin{array}{c}0.20-2 \\
00\end{array}$ & 2.00 & $\begin{array}{c}0.30-2 \\
00\end{array}$ & \\
\hline Kamenetsk-Podol'skoe & 92.33 & 2.17 & 0.48 & - & 0.26 & 0.50 & 0.08 & 0.49 \\
\hline Diatomite from the Inzenskoe deposit & 91.09 & 4.58 & - & 1.91 & 0.94 & 0.83 & - & 0.35 \\
\hline Dust waste from grinding of diatomite brick & 88.21 & 5.46 & - & 1.96 & 1.19 & 1.10 & 0.19 & 0.53 \\
\hline
\end{tabular}

Silicon dioxide is present in an amorphous state $(20-$ $50 \%$ of the total $\mathrm{SiO}_{2}$ mass) in tripoli from the Kutcinikskoc and Kamenctsk-Podol'skoc deposits as well as in diatomite. Tripoli from the Fokinskoe deposit is represented by amorphous silica ( $75-90 \%$ of the $\mathrm{SiO}_{2}$ mass).

$\mathrm{X}$-ray diffraction patterns with reduced intensity (the tripoli intensity is referenced to the intensity of quartz. sand) clearly show the presence of erystalline structure of low-tcmperature trigonal quartz in quartz sand and the absence of such in tripoli. The diffraction pattern of the production wastes from the terminal hopper at OMMBW is presented in Fig. 1.

The diffraction pattern of wastes from the cyclone dust separator is identical to that of wastes from the terminal hopper. The presence of crystalline structure of quartz in the OMMBW production wastes can be clearly seen in the dif- fraction patterns. The high content of silicon dioxide makes it possible to use the analyzed silica-containing materials for hydrothermal synthesis of nanodispersed amorphous sodium silicate. Compared with crystalline silicon dioxide, its amorphous state (in tripoli and diatomite) assumes a stronger interaction with the alkali component.

Electron-microscope analysis performed with a JSM-5300 scanning microscope with a Link Pentatet (Oxford) energy dispersion analyzer showed that a characteristic feature of diatomite is a microporous structure of the constituent particles (Fig. 2) - shell of diatomaceous algae (pore size from 1 to $2.5 \mu \mathrm{m}$. the particles themselves are $20-100 \mu \mathrm{m}$ in size), which greatly increases its reactive surface. In diatomite the clay component is represented by nontronite $(1.590,0.445$, 0.206 , and $0.167 \mathrm{~nm}$ ). Breakdown of nontronite and forma-

TABILE 2.

\begin{tabular}{|c|c|c|c|c|c|}
\hline \multirow[b]{2}{*}{ Initial material content } & \multicolumn{5}{|c|}{ Mass content, $\%$} \\
\hline & $\begin{array}{l}\text { amorphous } \\
\text { silica }\end{array}$ & $\begin{array}{l}\text { Iow-temperature } \\
\text { modification } \\
\text { of quartz }\end{array}$ & calcite & hematite & $\begin{array}{l}\text { montmorillonite } \\
\text { group clay } \\
\text { minerals }\end{array}$ \\
\hline \multicolumn{6}{|l|}{ Quartz sand from the deposit: } \\
\hline Kichinginskoe & - & 96.0 & $1.0-1.5$ & $0.1-0.2$ & $1.0-4.0$ \\
\hline Churovskoe & - & $87.0-88.0$ & $1.5-2.0$ & 2.0 & $8.0-9.0$ \\
\hline Molding wastes & $2.4-2.5$ & $91.0-92.0$ & 0.5 & $0.1-0.2$ & $6.0-7.0$ \\
\hline \multicolumn{6}{|l|}{ Tripoli from deposits: } \\
\hline Kuteinikskoe & $15.0-20.0$ & $60.0-65.0$ & $2.0-3.0$ & $1.5-2.0$ & $10.0-11.0$ \\
\hline Fokinskoe & $60.0-80.0$ & $10.0-25.0$ & $2.0-3.0$ & - & $5.0-10.0$ \\
\hline Kamenetsk-Podol'skoe & $10.0-15.0$ & $60.0-80.0$ & $1.0-1.5$ & $0.5-1.0$ & $5.0-10.0$ \\
\hline Diatomite from the Inzenskoe deposit & $41.0-46.0$ & $44.0-50.0$ & - & - & $9.0-10.0$ \\
\hline Dust waste from grinding of diatomite hrick & $40.0-45.0$ & $43-48.0$ & - & - & $9.0-10.0$ \\
\hline
\end{tabular}




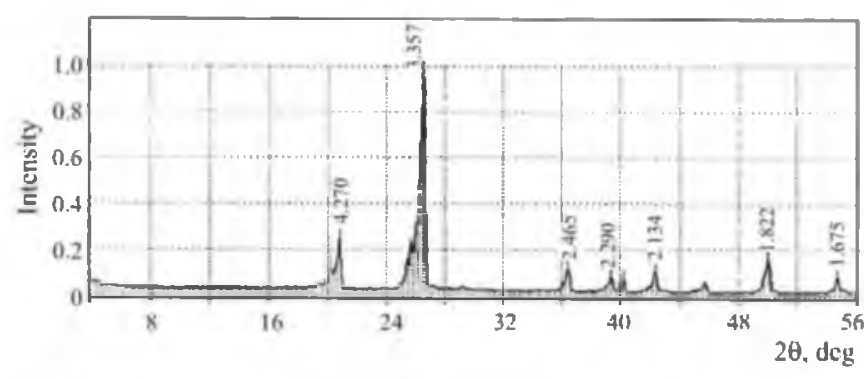

Fig. 1. X-ray powder pattem of OMMBW production wastes from the terminal hopper.

tion of iron wollastonite has been recorded in dusty wastes from grinding diatomaceous brick.

Nanodispersed amorphous sodium silicate was synthesized by the direct action of a solution of sodium hydroxide with a ratio giving a prescribed silicate modulus $2.2-3.8$ on silica-containing materials.

We have established experimentally that when nonactivated quartz sand interacts with a sodium hydroxide solution it is possible to obtain water glass with silicate modulus of no greater than 2.4. The following conditions are necessary: temperature $210^{\circ} \mathrm{C}$, alkali fluid pressure $2.2 \mathrm{MPa}$, duration of the isobaric-isothermal stage of the synthesis $6 \mathrm{~h}$.

When quartz sand which had been comminuted beforehand was used, the modulus of the water glass increased to 2.6 (other conditions being the same). It was established experimentally that when an air-pressure mill is used to comminute quartz sand the product obtained is of greater purity than the product obtained in a ball mill. The appearance of new crystalline phases with comminution of quartz sand is due to the presence of milling residue from the milling bodies and working surfaces of the ball mill.

It is suggested that two technological operations be combined to lower the synthesis temperature of nanodispersed sodium silicate (water glass) and increase the silicate modulus: comminution and chemical interaction on silica with an alkali component. These operations are combined in a ball mill. The formation of water glass was recorded $2 \mathrm{~h}$ after grinding of crystalline silica-containing materials in a water solution of sodium hydroxidc.

It was established that the yield of water glass increases with the mechanical - chemical working time (Fig. 3). Three basic stages have been identified in the process of mechanical - chemical working of quartz sand. The first stage lasts for $3 \mathrm{~h}$ and is charactcrized by slow dissolution of quartz sand, since large quartz grains break down at this stage. This is accompanied by their surface activation and chemisorption of $\mathrm{Na}^{+}$and $\mathrm{OH}$ ions. Free energy appears as a result of the formation of defects in the crystal lattice of quartz. At the sccond stage (duration $4 \mathrm{~h}$ ) the water-glass yield increases sharply; this is explained by the high rate of dissolution of activated quartz. At the final (third) stage the water-glass content essentially does not increase. This is due to a de-
Fig. 2. Diatomite from the Inzenskoe deposit.
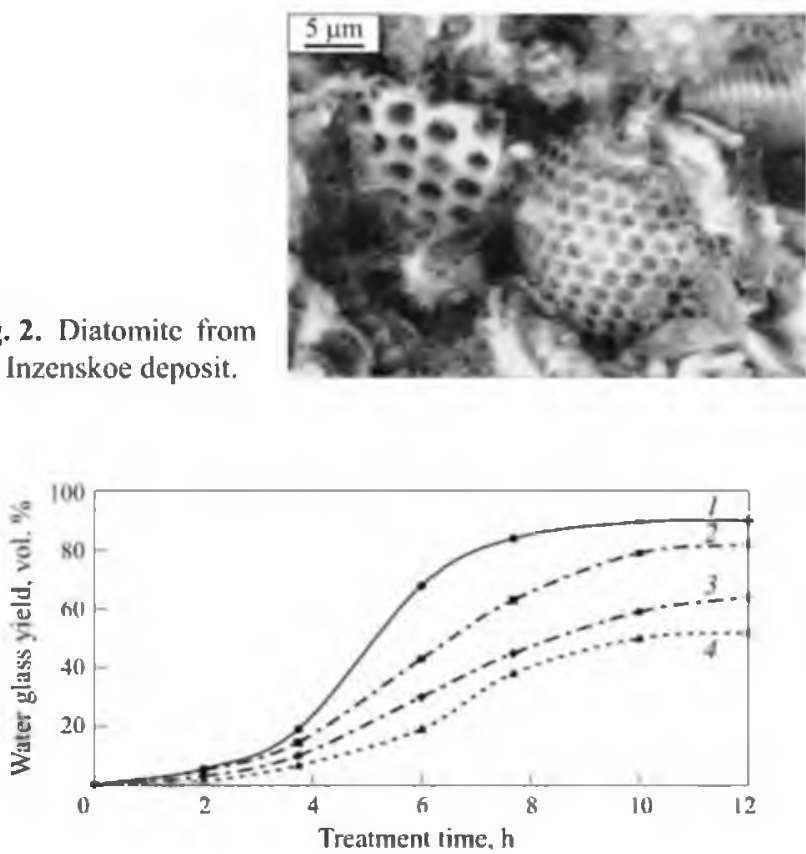

Fig. 3. Effect of the mechanical-chemical treatment time on the yield and silicate modulus of water glass: $1,2,3,4)$ the silicate modulus $2.6,2.8,3.0 .3 .2$, respectively.

crease in the sodium hydroxide concentration and, in consequence, the low solubility of silica.

Mechanical - chemical working made it possible to decrease the synthesis temperature of water glass under hydrothermal conditions. Thus, temperature $140-150^{\circ} \mathrm{C}$ and pressure $0.4-0.5 \mathrm{MPa}$ are required to oblain water glass with silicate modulus 2.6 from quartz sand, and autoclave-free treatment at the boiling temperature is sufficient when silica-containing molding wastes from metallurgical machine-building enterprises are used.

When Kamenetsk-Podol'skoc tripoli was used, water glass was obtained only after treatment of an alkali-silica mixture at the boiling temperature. A suspension based on tripoli from the Kutcinikskoe deposit manifests an adhesive capability after $8 \mathrm{~h}$ of mechanical-chemical working. To obtain water glass based on tripoli from the Fokinskoe deposit mechanical - chemical working for $6 \mathrm{~h}$ is required, but the adhesive properties in the suspension are already seen $1 \mathrm{~h}$ after treatment starts.

Natural diatomite was used as a basis to synthesize black water glass with yicld $10-15 \%$ by volume. The water glass based on dusty wastes from grinding of diatomaceous brick was not colored, and its yield was five times higher.

Water glass from OMMBW production wastes is dark brown (based on wastes from the terminal hopper) and light brown (based on wastes from the cyclone dust separator).

Using scanning electron microscopy (Quvanta 200 3D with an integrated Pegasus 2000 system for microanalysis, a Sapphire $\mathrm{x}$-ray detector with an ultrathin window $-\mathrm{Be}-\mathrm{V}$ element range) it was established that the microparticles ana- 
TABLE 3.

\begin{tabular}{|c|c|c|c|c|c|c|c|c|c|}
\hline \multirow{2}{*}{ lnitial material component } & \multicolumn{8}{|c|}{ Mass content. \% } & \multirow{2}{*}{$\begin{array}{l}\text { Silicate } \\
\text { modulus }\end{array}$} \\
\hline & $\mathrm{SiO}_{2}$ & $\mathrm{Al}_{2} \mathrm{O}_{3}$ & $\mathrm{Fe}_{2} \mathrm{O}_{3}$ & $\mathrm{FeO}$ & $\mathrm{CaO}$ & $\mathrm{MgO}$ & $\mathrm{K}_{2} \mathrm{O}$ & $\mathrm{Na}_{2} \mathrm{O}$ & \\
\hline $\begin{array}{l}\text { Quarzz sand from the Kichinskoe } \\
\text { deposit }\end{array}$ & 56.68 & - & - & - & - & - & - & 22.50 & 2.6 \\
\hline Molding wastes & 67.11 & 6.57 & 0.23 & 0.14 & 0.37 & 0.19 & 0.54 & 23.49 & 2.9 \\
\hline \multicolumn{10}{|l|}{ Tripoli from the deposits: } \\
\hline Kuteinikskoe & 56.22 & 7.28 & 1.19 & - & 1.29 & 0.45 & 0.72 & 19.30 & 3.0 \\
\hline Fokinskoe & 59.86 & 5.28 & 1.59 & - & 0.54 & 0.70 & 0.79 & 24.08 & 2.6 \\
\hline $\begin{array}{l}\text { Dust waste from grinding } \\
\text { diatomaceous brick }\end{array}$ & 68.02 & \multicolumn{2}{|c|}{2.89} & - & 3.29 & - & - & 25.80 & 2.7 \\
\hline
\end{tabular}
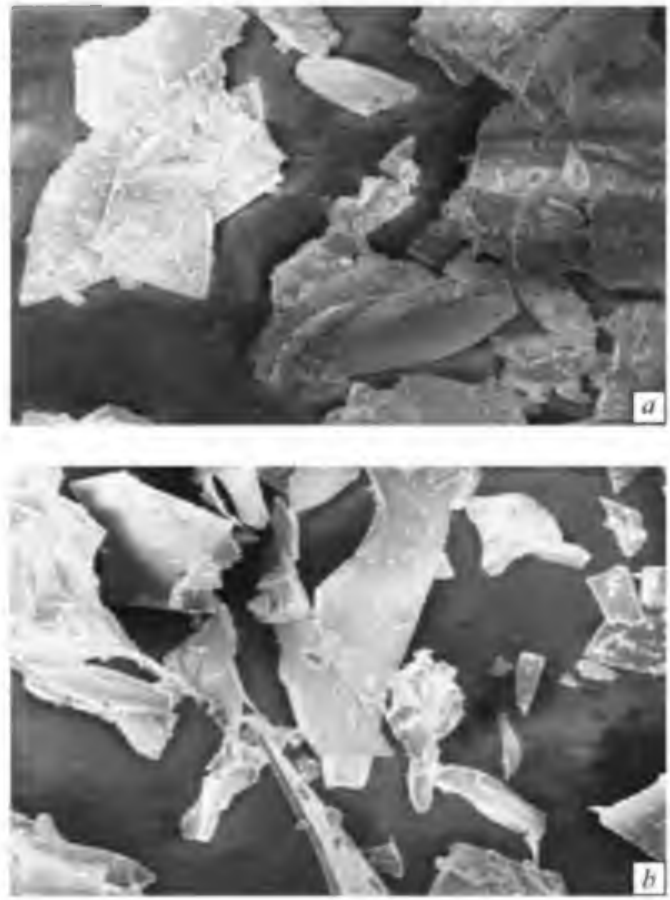

Fig. 4. Electron-microscope photographs of dehydrated products of synthesis based on dusty wastes from a cyclone dust separator (a) and terminal hopper (b).

lyzed possess clcavage surfaces characteristic of a glassy state (Fig. 4).

$\mathrm{X}$-ray structural analysis showed that when quartz sand undergoes mechanical - chemical treatment, changes occur

TABLE 4.

\begin{tabular}{lccc}
\hline \multirow{2}{*}{\begin{tabular}{l} 
Initial material \\
\cline { 2 - 3 }
\end{tabular}} & \multicolumn{2}{c}{ Molar content, \% } & $\begin{array}{c}\text { Silucate } \\
\text { modulus }\end{array}$ \\
\cline { 2 - 3 } & $\mathrm{Na}_{2} \mathrm{O}$ & $\mathrm{SiO}_{2}$ & \\
\hline Silica wastes: & & & \\
$\quad$ from terninal hopper & 30.06 & 69.94 & 2.34 \\
from cyclone dust separator & 24.73 & 75.27 & 3.04 \\
\hline
\end{tabular}

in the crystal structure of the low-temperature trigonal quartz. No substantial changes in the initial crystalline phases occur in tripoli from the Kamenetsk-Podol'skoc deposit. In tripolis from the Kuteinikskoe and Fokinskoe deposits, the intensity of the reflections corresponding to lowtemperature trigonal quartz. decreases, and after an interaction period of $8 \mathbf{h}$ these reflections transform into a large diffuse rise in the region $2 \theta=14-30^{\circ}$.

The montmorillonite clay co-minerals are adsorbents. During synthesis the sodium ions are adsorbed on the surface of the clay minerals. This slows down the rate of formation of water glass based on natural rocks containing clay minerals (tripoli from the Kamenetsk-Podol'skoe deposit and natural diatomite). Consequently, when heat-treated silica-containing materials are used (multiwastes from metallurgical machine building works, dusty wastes from grinding diatomaceous brick) the yield of water glass increases. This occurs not only because of temperature and the mechanical defects of the quartz. grains, but also as result of the onset of breakdown of clay minerals. since in this case they sorb fewer sodium ions. This is possible for heating approximately up to $650^{\circ} \mathrm{C}$.

The black color of water glass based on natural diatomite is due to the interaction of sodium hydroxide with humic acids.

Chemical analysis confirms the formation of water glass with silicate modulus ranging from 2.6 to 3.0 . The chemical composition of the dry residue of water glass is presented in Table 3 .

Data on the composition of a sodium silicate sample synthesized from OMMBW wastes were obtained by energy dispersion analysis. The ratio of silicon dioxide to sodium oxide ranged from $2.34: 1.00$ to $3.04: 1.00$. The chemical composition of the water glass obtained is presented in Table 4 .

The method of direct low-temperature hydrothermal synthesis is the most efficient method for producing water glass based on tripoli from the Fokinskoe deposit, since autoclaving is not required. This can be explained by the fact that the content of dissolved silica is highest in the tripoli from this deposit. 
TABLE 5.

\begin{tabular}{lccc}
\hline Index & $\begin{array}{c}\text { Conven- } \\
\text { tional } \\
\text { method }\end{array}$ & $\begin{array}{c}\text { Technology developed } \\
\text { for producing water glass } \\
\text { based on silica }\end{array}$ \\
\cline { 4 - 5 } & crystalline amorphous \\
\hline $\begin{array}{c}\text { ('onsumption of fuel equivalent } \\
\text { per production unit. } \mathrm{kg} / \mathrm{ton}\end{array}$ & $450.0^{*}$ & 41.0 & 6.5 \\
$\begin{array}{c}\text { Maximum possible silicate } \\
\text { modulus }\end{array}$ & 3.0 & 3.8 & 3.8 \\
\hline
\end{tabular}

- According to data from the Kherson Glass Works.

The method for producing water glass based on tripoli (amorphous silicon dioxide) and quartz sand (low-temperature modification of trigonal quartz) was tested under commercial conditions. Tripoli was used to produce 30 tons of water glass and quartz sand was used to produce 90 tons of water glass. which corresponds to GOST 13078-81 requirements. The water glass obtained was used under commercial conditions as a core binder and a stabilizer for clay suspensions as well as for fabricating efficient. noncombustible. ecologically clean, heat-insulating materials. The main advantages of the proposed technology are presented in Table 5 - lower consumption of fuel and expansion of the range of silicate modulus for the glass obtained.
In summary, raw materials with mass content of silicon dioxide greater than $81.5 \%$ can be used to obtain water glass by direct hydrothermal synthesis.

Depending on the degree of crystallization of the silicon dioxide. two methods for producing water glass were obtained. These methods permit the following:

substantial reduction of energy consumption;

the use of unconditioned initial materials (dusty quartz sands. wastes from metallurgical and other production enterprises);

substantial reduction of the emission of carbon, sulfur. and nitrogen oxides into the atmosphere;

the use of serially manufactured equipment;

the elimination of expensive and energy intensive equipment such as a glassmaking furnace.

Equipment from the Group Use Center of the Belgorod State University (State contract No. 02.552.11.7017 FTsK) was used to perform this work.

\section{REFERENCES}

1. P. N. Grigor'ev and M. A. Matveev. Hater Glass [in Russian]. Gosstroiizdat. Moscow (1956).

2. I. R. Fishman. "Modern methods for producing water glass: Review," in: Technology: Economics. Organization of Production. and Control [ in Russian], TsNIITEIryazhmash. Moscow (1989). 